\title{
Unintended Consequences?
}

\section{Human Rights and the Development of A Twenty-First Century Peace}

\author{
Architecture ${ }^{1}$ \\ Oliver P. Richmond \\ Forthcoming in Australian Journal of International Affairs
}

Keywords: peace, liberal peace, human rights, global justice

\begin{abstract}
The 'long peace' of the last twenty-five years has linked various forms of intervention-from development to peacebuilding and humanitarian intervention- with human rights. This 'interventionary system/order' model has premised its legitimate authority on expanded versions human rights, connected to liberal frameworks of democracy, rule of law, and capitalism in order to connect peace more closely with justice. Human rights offer a tactical way forward for those interested in conflict resolution, but this has led to unintended consequences. Unless conceptions of rights are continually expanded as new power structures and inequalities are uncovered and challenged, philosophical and material matters of distributive and historical justice remain.
\end{abstract}

\footnotetext{
${ }^{1}$ I would like to dedicate this article to the memory of Professor Nick Rengger of the University of St Andrews, and Professor Chandra Sriram of the University of East London, both of whom contributed to my thinking about these topics enormously. Thanks also to several anonymous reviewers for their very helpful comments. All errors are the author's responsibility.
} 


\section{Biography}

Oliver Richmond is a Research Professor in IR, Peace and Conflict Studies at the University of Manchester and a Fellow of the Royal Society for the Arts. He is also International Professor, College of International Studies, Kyung Hee University, Korea, and Visiting Professor at the University of Tromso. His publications include Peace Formation and Post-Conflict Political Order, (Oxford University Press, 2016), Failed Statebuilding vs Peace Formation (Yale University Press, 2014). He is editor of the Palgrave book series, Rethinking Peace and Conflict Studies, and co-editor of the Journal, Peacebuilding. 


\section{Introduction}

Human rights have long been seen by the international community to be essential for peace with justice, in particular because they contribute to more sustainable and positive responses to structural and cultural violence (UN, 1984: Bailliet \& Larsen, 2015: 9). Controversial amongst power-holders in conflict affected states, as well as sidelined by key geopolitical actors in the international system, even basic rights appear weakened as geo-political and geo-economic forces have sharpened recently, coinciding with a loss of legitimacy for liberal forms of peacebuilding.

A growing tension between peace processes, peacebuilding, claims for rights from local actors, and broader questions of justice (eg economic, social, cultural, environmental, and thus global) has developed over the last three decades. Their relationship threatens to undermine the legitimacy of the contemporary international architecture. The 'long peace' of the last twenty-eight years, during which period conflicts have tended to be regional or internal rather than systemic, has linked various forms of intervention-from development to peacebuilding and humanitarian intervention. A basic form of human rights has been essential to this endeavour, assumed to be universal within a state-centric framework, partly because they are so limited- and this pragmatic. The concept of peace has developed from a victor's peace- imperial or state-centric- to a liberal peace, and onwards towards a hybrid peace (Richmond, 2005). However, there has been significant pressure on human rights, which has long prevented their substantive expansion. Yet, if they are to contribute to peace with justice in anything more than negative form new conceptions of rights would have to emerge.

As opposed to the model of a state-centric international system, an 'interventionary system'2 model of international governance has premised its legitimate authority on promoting and enforcing human rights, also connected to liberal frameworks of democracy, rule of law, and capitalism. As an unintended consequence, peacebuilding has expanded in practice and conceptually far beyond basic human rights,

\footnotetext{
${ }^{2}$ By this I mean a system predicated on multiple and continual forms of intervention, from developmental, economic, political, and military, rather than on territorial sovereignty in which intervention is exceptional.
} 
implying progress towards global justice, connecting with the work of John Rawls, Charles Beitz, and Henry Shue among others (Moyn, 2018: 153-172). While it is laudable in ethical terms, most scholarly and policy work assumes that rights are fixed in aspic, this being the best way to defend them under the conditions of geopolitics. Consequently, they have left behind their ethical and philosophical intent.

Given the growing concern about subaltern and localized political claims (Morton, 2007: 96-97), a more plausible logic related to the shift in concepts of peace from negative to positive, everyday and hybrid, points to an expansion of rights (the right to have more rights as more abuses are discovered) (Arendt, 1951: DeGooyer, 2018: 4) over time, driven by subaltern claims. FDR Roosevelt's "New Deal" was an early indication of this logic with its projection of a range of new rights (Moyn, 2018: 68), as was the later International Covenant on Economic, Social, and Cultural Rights (UN 1966). This expansion transcended the outlawing of state-centric war as a legitimate tool in international relations except under specialized circumstances (Hathaway \& Shapiro, 2017: xviii). It encouraged the slow embedding in international and national law of the idea that certain, increasingly complex institutions for organizing human relations are less prone to conflict when subject to complex interventionary processes designed around rights in liberal states.

This article outlines the tendency for rights to expand when connected to concepts of peace with justice, and the implications this has for intervention and forms of justice. It first assesses the relationship between order, rights and peace, before outlining the way in which growing claims for more rights and their connection with conflict resolution also expands the need for, and type of, intervention. It then examines how this dynamic relates to more sophisticated concepts of emancipatory peace with justice. The article concludes by looking at the more recent argument that expanding modern peace and rights frameworks would be better associated with debates about global justice rather than liberal peace.

\section{International Order, Rights, and Peace}

After the Cold War a more settled international system had appeared to emerge, for a short time at least. It was Euro and northern-centric, however, based predominantly upon the states-system and a material hierarchy which has undermined the idea that rights point towards global equality (Moyn, 2018: 6). This 
contradicted a later generation of human rights, such as ECOSOC's post-colonial version (UN, 1966: Cahill- Ripley and Hendrick, 2018), and the growing mobility of people, ideas, capital, resources, and technology. At the same time global hierarchies have been maintained, and these elements of order are in tension when viewed from the subaltern perspective. The state and the international framework of rights have been slow to respond to claims for expanded rights, whether material or cultural, despite ECOSOC and various Treaties on self-determination, minority rights, indigenous, women and children's rights since the 1960s. ${ }^{3}$ They appear more discursive than material, as a tactical compromise between the logic of rights and the logic of power. Yet, international human rights and humanitarian law, as well as international conventions place rights at the heart of order, peace, justice and the liberal state, linking them in order to build legitimate authority for the peace settlement, state and international architecture. Indeed, the UN's recent 'sustaining peace agenda' has continued to highlight how rights are effectively expanding, if only discursively, primarily because subaltern perspectives are being transcribed into international frameworks where plausible (UN 2018). This process underlines the gap between peace, the logic of global capital, Euro-centricism, and raison d'état. Power becomes entrenched and expands in the same way that rights do. Thus, the modern state, the international architecture, and global governance are currently suffering a legitimacy crisis.

The modern 'Anglo-sphere' (Vucetic, 2011) prioritizes trade and northern political and individual interests over rights as a mechanism for cooperation, development, and therefore for peace. The subaltern positionality (meaning the perspective of politics, power, authority, legitimacy, rights, and materiality from the perspective of those peoples negatively affected by inequality, violence, war and conflict, and existing power-structures-the view from below) is essential in order to understand the conditions for emancipation, peace and justice in this context. Yet, the subaltern requires support by powerful or influential elites, this being the assumption of critical, liberal, and other reformist debates about both peace and rights. Rights provide a shorthand cipher in a world of social diversity and complexity during a Rostowian shift from tradition to modernity (Rostow, 1960) requiring broad tools for military, political, economic, and social

\footnotetext{
${ }^{3}$ See various UN Treaties: https://treaties.un.org/
} 
intervention. Yet, 50 years ago, the International Covenant on Economic, Social, and Cultural Rights, now rarely mentioned, endeavoured to expand the global rights frameworks in ways which echoed post-colonial and subaltern, right claims, offering an alternative path of development and avoiding the logic that development was necessary for rights and intervention for both. ECOSOC pushed far beyond the first generation of human rights-and were roundly ignored by mainstream scholars and policymakers (Moyn, 2018: 6), in parallel with the attempt to dismantle the welfarist version of peace that had emerged in the West after WW2 in response to demobilization and the threat of communism.

Mainstream versions of human rights and their contribution to peace with justice followed the limited script that was possible for the superpowers to agree on in the early Cold War in a state-centric epistemology. A broad range of post-colonial, anti-colonial, and feminist thinkers concurred that liberal conceptions of rights in the geopolitical framework of the state and the Cold War did not do justice to the wider problems of distributive and historical justice, culture and identity, class and gender, selfdetermination or environmental sustainability. Human rights in more critical form, from the G77 to the Millennium Assembly or the Sustainable Development or Sustaining Peace Agendas (UN, 2015, 2016, 2018) thus offered various expanded iterations, to liberate the discourse of rights from northern states, from Euro-centricism, from racism, geopolitics, and from capitalism. They pointed toward more positive, hybrid forms of peace (Richmond, 2015), and expanded versions of rights by taking an everyday perspective of how the subaltern participates in the production of hybrid political orders (Boege, Brown, Clements et al.. 2008). This was understood in legal and material terms, as well as connected to matters of identity, history, and culture: superficially, this points to transitional justice, but in philosophical terms it requires global justice.

The failure to expand rights in practice has limited their capacity for conflict resolution as an ethical and material practice. Conflict resolution has been forced operate within the constraints of the legacy of colonialism, of patriarchy, of geopolitics, nationalism, territorialism, state-centricity and capitalism. The term "power-sharing" encapsulates this compromise in practice, whereby elite, state, and geopolitical/ economic, power-structures remain dominant even if moderated by a peace agreement. The lack of political will to resolve these tensions since has also undermined the position of rights. It has also provided escape 
routes for political elites who otherwise would be 'beheaded' (in the Foucauldian sense) (Goulder, 2015: 16) by legally implemented rights frameworks, causing elite resistance as in conflict-affected societies like Colombia or Cambodia. Cultural, indigenous, family, and environmental rights further emphasis the need for revised understandings of peace, though they have not been adopted at a systemic level in the way that the early generation of human rights were. This has also undermined the legitimacy of peacebuilding, which has become more dependent in a broad range of interventionary practices instead.

This contradiction has historical intellectual roots. Behind all of the proposals for a more peaceful international order in history such tensions were dealt with by the old idea of a commonwealth, promising broader public goods for all, while balancing being territorialized, often racialized (Anievas, Manchanda, and Shilliam, 2015), connected to power and the state (Elden, 2013). EH Carr saw the formation of European wide institutions after World War II as both practical and necessary for such a process, which might possibly lead to a 'post-state international society' (Carr, 1939) and human rights were an essential component of the attempt to build a global governance system. One needed to know what the rights of subjects governed by such a system might be, and a standard set of legal norms were needed. Such an escape from the logic of territorial nationalism that had wreaked so much havoc over the last century would be necessary to provide a substitute for war, Carr thought, as an ordering mechanism, overcoming what Marx had identified as a destructive relationship between land, capital, and labour (Elden, 2013: 9). It would take the people towards a more pluralist form of community, perhaps even a global polis, often via a welfare state as in post-war Europe, in order to give material reality to the legal equality inherent in human rights frameworks.

Following this process that was slowly connecting peace with justice, human rights, democracy, and prosperity did slowly began to displace sovereignty, authoritarianism, and oligarchy in many parts of the world, and territorialism has been under question as a basis for sovereign power, as the evolution of the UN and EU has indicated. The second half of the twentieth century saw international institutions, law, and norms, gradually built into an established international and state peace architecture in which there was to be an envisioned synergy between international liberal norms underpinned by the United States and the welfare state (as a compromise between the superpowers' polarized ideological positions). Intervention maintained 
the balance necessary for the liberal peace and by the 1970s rights were becoming a significant rather than aspirational discourse in IR. After the end of the Cold War this system was increasingly parallel to, and often in tension with, global capitalism as neoliberal frameworks of state, international trade, and indeed of global and state governance emerged. Though most people have experienced greater rights and mobility and benefit from transnational networks, the state and capital still simultaneously define most lives, through historic power-relations, which echo colonialism and capitalist priorities in international order. Revanchism remains a risk because the international order is still defined by the territorial state, which is a vehicle for subterranean forms of power in contradiction to rights, or their expansion.

A rights-based international order inevitably needs a system of intervention, whether in soft forms of diplomacy and economic or social programmes or harder, military and strategic terms. This is what peacebuilding and Responsibility to Protect (R2P) have come to mean in historical context: the enforcement of basic conceptions of rights emerging from Western conceptions of domestic political order. However, contrary to the western, twentieth century scholar and policymaker's apparent post-war consensus about a rights and law based international trading order based on social forms of democracy and global redistribution, the contemporary 'interventionary order' is now related to the goal of neoliberal forms of peace, which have been much more difficult to socially legitimate around the world. The interventionary order has utilized liberal international institutions, INGOs, IFIs, and regional organizations for the biopolitical and governmental projects associated with programming the liberal peace and neoliberal state. It signifies a range of interventionary practices through which the west modernizes the rest of the world while maintaining the historical advantage of its core states. It has all but abandoned the notion of a rights-based order with material dimensions of equity and equality, which would, under pressure from non-aligned or global south movements, eventually expand into an international system based upon historical and distributive justice. Thus, conflict resolution, peacebuilding and statebuilding have become denuded of ethical content (though discursively it seems significant, as in the 'sustaining peace' agenda) (UN 2015).

Rather than progress towards peace-with-justice the structure of International Relations (IR) has shifted from a state-centric order to a system of interventionary networks, practices, and discourses. These emanate from a historical core group of dominant states and actors across each region (the United States, China, 
India, Russia, the United Kingdom, Brazil, and the institutions they create or are members of, from the United States, World Bank, AU, to the EU). Networks of peripheral social agency swirl around these cores. At best, this evolution has led to a negative form of hybrid peace based upon northern liberalism but with different biases towards the economy or key elites. This has enabled a general denial that rights and law were connected not to the interventionary maintenance of a Washington or New York consensus (Pugh, 2006), but also to the goals of emancipatory peace and justice (whether for political, social, cultural, or economic rights, of for self-determination).

Rights offer an expansionary process-a top-down process of norm diffusion and a grass-roots and upwards cascade-that distils the basic essence of such claims, albeit in a limited and imperfect manner, producing legitimate authority upon which governance depends. This is also the basis for the traditional measure of legitimate authority: efficiency and effectiveness are connected to the state's capacity to deliver a narrow version of rights. Nevertheless, legitimate authority the world over has struggled to constrain subaltern demands to such a narrow version, meaning that it has partly been displaced by more networked and multi-scalar versions (such as with international law, multilateralism, and regionalization).

\section{Subaltern Claims and the Expansion of Rights for Conflict Resolution}

Transformation and "progress" in IR have been identified and directed from a vanguardist and elite positionality, which has generally followed hegemony and globalization. Liberal peace has been limited to developing within its parameters, focusing on security and development burnished by basic versions of rights, rather than responding to subaltern claims. As time moved on after the post-war settlement the more western political leadership moved away from material rights and welfare as a solution to war towards, abstract rights and global governance, increasingly of a technological nature (Owen, 2015). This means that ethically peace is created and constrained either by the state and international architecture, or global markets and technology, rather than responsive to such claims, as the states-system cannot engage fully with subaltern claims (Hovey, 2004: 241-254). 
The evolution of the discourse of rights suggests that progress has to be understood from the point of view not of preserving existing power structures or promoting global capital, but from that of the subaltern. The logical outcome of this historical dynamic is that intervention and rights claims are closely linked, along with the evolution of constitutional and international law, hence the initial prevalence of social democracy after WWII (Moyn, 2018: 11). If the social democratic state is removed from this equation, then only rights and intervention remain, undermining its legitimacy. As rights are not static, this is compensated for by new subaltern claims made from the midst of conflict-affected situations. It is an expression of their tactical agency as can be seen in the somewhat unlikely but major expansion of rights claims against entrenched power structures over the last century. The state and international frameworks of rights must therefore also expand in line with the uncovering of instabilities in the global architecture, starting with the subaltern and moving across networks and scales. The current mixture of realist and liberal international architecture, founded on territorial sovereignty, has become an obstacle to such a process, however.

Thus, in a paradoxical manner an interventionary system has become necessary because of subaltern pressure to expand rights. The experience of R2P, as its contemporary culmination, suggests the connection between intervention, progress and subaltern contributions are weak, however. International actors use the doctrine to facilitate conflict resolution by preventing and punishing atrocities, which provides a basis for the expansion of subaltern claims towards a more positive form of peace. However, this creates enormous pressure on the doctrine, to which it cannot respond because of a lack of resources and the limitations placed upon it by the norm of non-intervention (and sometimes self-determination) as well as the nature of the contemporary neoliberal state-based peace settlement (Richmond, 2014). Distant, elite governance fails to identify the salient issues, and uses broad-brush tools, resulting in a compromise and a negative form of peace that rarely settles claims for even basic human rights nor establishes legitimate political authority within the state framework. The legitimacy of any peace has to be augmented by international engagement. Trusteeship forms of conflict resolution thus become paradoxical because though they offer basic rights they also undermine autonomy, producing great tension-as can be seen in both Kosovo and Bosnia (Visoka, 2017: Richmond and Franks, 2009), where the population wanted expanded rights and blamed the international community for slow progress. Conversion into a rights discourse or practice at the international 
level, or indeed at the state level, is a process which happens in slow, historical rather than reactive time. Subaltern claims are necessary for the legitimacy of the states-system and its interventionary practices, and yet they also overstretch international capacity and political will. What has emerged is a tendency for policy makers to expand the concept of peace, development, and rights (and ultimate intervention) doctrines discursively, without expanding material capacity or addressing the internal contradictions inherent in their expansion (UN General Assembly and Security Council, 2018).

Subaltern agency is weak and often inaudible or ignored, however, because peace theories and conflict resolution tends to value liberal discourse, rational compromises, and sees rights as more legal than material (Moyn, 2018: 11). Such agency is located in wider relational social, political, economic and environmental systems, in an isolated or reciprocal rather than dominant manner (Qin, 2018: 120). This limited, but nimble and networked agency does not mean more direct power, but it means complex possibilities for change and reform exist in unlikely agents and spaces. It is distributed rather than intentional agency, multi-track and multi-dimensional, forming 'swarms' through micro-solidarities and micro-politics, which are often incidental in nature (Dürbeck, Schaumann and Sullivan, 2016: 118-136). This helps understand how social peace constituencies, actors, and organizations form in conflict-affected societies over time through an organic buildup of engagements and networks, often transversally and transnationally supported. The peace communities in Colombia or the intercommunal groups in Cyprus or Northern Ireland provide good examples (Alther. 2006: 278-291: Zink, 2008: 579-612). The so-called agentic-pluralism it offers may well be the basis for legitimacy at the social level, and it is also the basis for hybridity across entangled and relational networks (once understood as cooperation and interdependence) which makes the state itself for likely to reform and accrue legitimacy (Millar 2018). The subaltern may require intervention (broadly defined from the work of donors and INGOs, to the UN system's peacebuilding approaches, and peacekeeping) to modify the otherwise immutable structures of domination they face in their search for rights as a way of driving conflict resolution. Again, this might be seen in the case of civil society and conflict resolution groups in Northern Ireland, and many others (Marchettia and Tocci, 2009: 201-217). 
Liberal modernity attempted to resolve such tensions through fixed human rights, the varied social contract with the potentially social state (Piketty, 2014), liberal institutions, and neoliberalism. However, the increasingly densely networked and heavily cooperative international order remains heavily marked by power and exclusion, long referred to in the liberal peace critique and more recently in discussions about the limits of neoliberal global governance and states in making peace (Richmond, 2005, 2014: Chandler, 2010). A 'subaltern deficit' has undermined peace with justice. Despite these difficulties, the international order is more networked, cooperative, interdependent and transnational than it has ever been in history (Slaughter, 2004: 283-327). This is so with either of the modern state's current main forms-western liberalism and neoliberalism, or 'managed' democracy and authoritarian capitalism elsewhere.

Previous colonial, Marxist, liberal internationalist, critical, neoliberal projects for emancipatory peace tended to argue that social agency can overcome direct and structural forms of power, and coalesce around a more emancipatory international agenda if given the space by the intervention of powerful actors, whether government or international. When part of a peace process, as they inevitably are, globalization and neoliberalization have sometimes re-asserted neo-patrimonial frameworks of authoritarianism over individual rights in contradictory processes, whilst in other areas also improving rights and justice (Hinnesbush, 2015: 335-357). Global capitalism and related 'small state' forms limit the capacity of governance at international and state levels to reform, to intervene to provide public goods, justice, and equality, even if trade produces other forms of cooperation. It undermines international institutions' capacity, the role of diplomacy, and the resourcing behind programming. Thus, there is a mismatch between a positive form of peace in hybrid form, geopolitics and the weakened structures of global governance, and the state's roles in evening out social inequality where the state is mainly limited to a 'night watchman' type role, or buttressed by international peacekeeping, mediation, peacebuilding, and the role of civil society. This is all worsened where peace and justice are determined (though not defined by) the structural forces of global capitalism and geopolitics: peace remains unanchored and unable to lock-in reform through constitutional or international law, enforcement activity, and discursive agreements at social of diplomatic levels cannot be reached where there is no centering momentum behind peace. 
The broadening of basic human rights towards new and more sophisticated generations has been constrained a consequence, thought have been some positive consequences. For example, the UN's Capstone Doctrine pointed to how the legitimacy of a peace operation should be present in the eyes of local populations if such a mission is to succeed (UN DKPKO, 2008). The US and UK militaries, have also made similar assertions. R2P was meant to secure the rights of the human over sovereignty (though this has been undermined by northern and southern objections) (Bellamy, 2015: 161-185). The 'post-2015 Development Agenda' has added a global material context of ever increasing, sustainable development across the world, as does the recent "Sustaining Peace" agenda (UN 2018), both of which point to the need to expand rights.

The tension between elite political constraints on the expansion of rights and social pressure for political claims to be translated into new rights has provided the basis for an understanding of peace that can be seen more clearly not in political liberalism but in work on global justice.

\section{The Challenges of Expanding of Rights in the Existing International Order}

Complex constraints to the expansion of rights exist. Firstly, the first layer of the states-system maintains both basic interests, territorial configurations, and a basic order based on fixed structures and populations (as defined in the 1933 Montevideo Convention). Secondly, the liberal international peace architecture, running from the UN Charter through to the various conventions, resolutions, and agendas, and doctrines of the postCold War era, offer a series of rights and processes which constrain and improve the states-system from below (civil society and law) and from above (international law and conventions, as well as global civil society). This may significantly develop its contribution to peace to add notions related to rights, representation, and development. It has also expanded the rights of citizens affected by war, offering humanitarian assistance, mobility, reconstruction, as well as opening up the terrain of environmental rights and post-conflict transitional justice.

These were significant achievements, but they have arrived at the limits of state sovereignty relating to the geopolitical, realist layer, and because of Eurocentric limits to the understanding of social, economic, and political organization, according to the liberal-institutionalist layer. Thus, in a post-colonial era a new layer of rights needed to be developed in order to rectify the limits and faults of the older layers, resolve the 
contradictions with the new claims being made at the subaltern level across scales and networks. This points to evolving notions of global justice.

In turn this means new layers of rights and political architecture now have to reflect the nodal, networked, mobile and relational world that is coming into existence in which alterity coexists not passively as under cosmopolitanism, but through more direct, multi-level and multi-vertical relationships. Hybridity, temporality, and mobility are not fixed to institutional, norms, law or standards. They emphasise the political, not as solely power based, but also driven by subaltern claims. Universal rights are also not necessarily the goal, though there is a strong sense that peace and order are based upon the right to claim rights as a part of ongoing self-and institutional formation, and relate peace to critical agency as much as to institutions, law or expert knowledge (Goulder, 2015: 72). The point is to push them forwards, not backwards. Thus, this layer has to be relational, but autonomy is important: it is certainly humanist but open to difference rather than structurally universalist, and mobile and networked, relational agency configures its political architectures rather than fixed citizenship and territorial sovereignty. The state is no longer the sole purveyor of rights (even if supported by international law and institutions), and its function has to promote a representative order in society as far as possible within a transnational, transversal, scalar context, rather than merely within its own borders. The state and the international has to respond to and find ways of meeting ever expanding rights claims in a mobile, trans-scalar and networked global justice order (Rist, 1996: 246), as anti-colonial and post-colonial, development, and other theorists have realized. Such a perspective can only be fully understood from a subaltern positionality (the view from below). Either structural violence is tolerated in the existing system, or progress points to systemic reform, often through complex forms of intervention, directly connected to complex local claims.

Indeed, the progress that has been made over the last two centuries might be said to have occurred mostly because of what were initially idealistic and often underground civil and social forms of activism and mobilization, which were adopted by elite leadership. As TH Marshall argued, citizens in the west gained civil rights in the eighteenth century, political rights in the nineteenth century, and social rights in the twentieth century (Marshall, 2009). A fourth layer would be related to new structural claims and new capacities for actors from local to the global scale: global justice in the light of new technology, mobility, 
and environmental limits. This development might be said to be increasingly represented in the international system, though not fully formally. This is includes the so-called ' $1{ }^{\text {st }} \mathrm{UN}$ ' of member states, the $2^{\text {nd }}$ of international civil servants, and the $3^{\text {rd }} \mathrm{UN}$ of non-state, NGOs, and other civil society actors, or perhaps a $4^{\text {th }}$ made up of those working in transnational, scalar, and sometimes transversal networks in order to improve rights and needs provision around the world (Weiss and Abdenur, 2014: 1749-1758: Weiss, Carayannis and Jolly, 2009: 123-142; Slaughter, 2004; Keck and Sikkink, 1998). When these converge with diverse societies around the world, peace may be said to have converged with the modern art of peaceful government in that expanding rights and global justice have been incorporated.

So far, the territorial state, and very specific states at that, dominate regional and global order, despite ever denser transnationalism, creating only basic rights and blocking their expansion precisely because it requires an engagement with global justice issues. Top-down and Weberian notions of state legitimacy and static citizenship are clearly now in contradiction to bottom-up, subaltern or Foucauldian versions of the agential subject (Di Palma, 2013) as well as with a networked and multi-scalar international system. These are sometimes in tension with liberal international norms, and global capital produces further and fundamental tensions with expanding rights frameworks. Thus, the current art of peaceful government is aligned more with geopolitical or economic hegemony, not the twenty-first century, mobile and justiceseeking subaltern-citizen. Yet, all of these tensions are causing further rights claims to be made. Subaltern rights claims expand across networks and scales, and cascade from the bottom-up, placing legitimate authorities at state, regional and international level under great normative and increasingly legal pressure.

This points to tension over whether intervention creates a universal but hierarchical world order, or entwined orders dealing with difference and inequality and a growing contradiction between state autonomy and a legitimate international order. Struggles for autonomy, human rights and democracy, for decolonization and sovereign equality with the states system may contradict social and distributive justice. All of these factors, as Bull and Watson once argued, have influenced the global milieu if not decisively (Bull and Watson, 1984). Indeed, liberal thinkers envision that the liberal international order will continue to expand, either by incorporating other states, or through various forms of military, economic, social, and political intervention, leading to a fuller realization of universal human rights, international law, courts, 
collective governance, and multi-lateral institutions, probably at the expense of sovereignty and unipolarity (Ikenberry, 2011: 296). Eventually this might lead to a world state or federation, as well as a kind of global Marshall Plan in order to produce relative equality for its members. However, the reality today is that there are multiple systems of governance (as mentioned above). These systems are in tension with each other rather than aligned, and the international architecture is now subject to great political tensions over the expansion of subaltern claims against the basic universal standards that have been set. Neoliberal governmentality and expanded rights are further destabilizing an agonistic international system shifting towards multiscalar and networked formats.

From a subaltern perspective, injustice, inequality, and instability, as well as systemic insecurity and unsustainability remain all too visible: forty to sixty states are still regarded as fragile today. The sheer scale of state fragility undermines the liberal notion of an effective state able to even out material and rights inequalities. The so-called 'Beijing consensus' has diluted the previous Washington or New York consensus on the liberal peace, as has the widespread emergence of authoritarian-capitalist states, managed democracy and oligarchical forms of capitalism (Hudson, 2003: xvi). Rights appear to expand on paper but are being compressed by material factors.

Interventionary practices related to conflict resolution, peacebuilding, and statebuilding must be expected to provide a platform for expanded rights claims, which means the legitimacy of intervention might be undermined if it cannot respond. However, state level actors may tend to interpret rights in connection with state level interests or self-determination, thus shifting their ethical basis from subaltern issues to geopolitics and nationalism. This might be seen in the intervention in Kosovo in 1999, which provided the basis for a new governance system on the basis of human rights run partly by international actors (Visoka, 2017). Expanded claims for rights, including for identity and autonomy soon arose, which were responded to by the UN Mission (UNMIK) by raising the normative standard bar (with their policy "Standards before Status"), which led to further responses by an increasingly coordinated Kosovar government for self-determination. Eventually, the UN was undermined and a unilateral declaration of independence ensued, this being the ultimate arbiter of rights for many Kosovars, even if international actors placed their own preferences and standards first. 
The limited potential for expanded rights claims in the existing international system raises the question of what type of international system and peace might be required to overcome this structural and ethical weakness, which threatens the integrity of contemporary concepts of peace?

\section{Expanded Rights and Peacebuilding in a Post-Liberal Order}

From these contradictions, the nature of a post-liberal, and positive hybrid peace can begin to be discerned. It would be post- geopolitical and post-geo-economic, if social legitimacy is to be achieved more broadly (Hudson, 2004). This means centralized, liberal state authority, regional and global state-centric balances of power, and simple conceptions of free trade could not underpin a just and sustainable peace agreement or peacebuilding process without significant modification. Agonistic reconciliation of identities within a framework of heterogeneity would be essential. A progressive vision of improving social rights and material conditions would attract societies towards this position, either through structural change or through mobility (exit as opposed to voice in the face of the failure of the state or international to mitigate broad issues of violence). This would enable the tendency of human rights to cause upwards cascades of rights claims emanating from a subaltern positionality towards and across global networks of relationality (Qin, 2018: 120) without undermining the evolving international architecture.

This would recognise much deeper dynamics associated with justice, identity, sustainability, networks, scale, mobility as well as environment issues. Thus, the state, the international, and capital must offer an eventual prospect of pluralism and relative equality in norms, identities, laws, rights, institutions, and material standards in a deterritorialised manner, cognizant of the emerging dynamics of 'digital international relations'. There would probably be a basic agreement on the nature of a universal and global moral community through the UN, in very thin terms, and the modes by which needs, rights, interests, and identities were mediated and adjudicated in the context of global networks, mobility, scale jumping, and the expansionary quality of rights discourses. It would need to respond to nature, technology, consent, and rights as mutually entwined determinants of peace and justice, probably aimed a progress towards equality (Hurrell, 2007: 308-316). It would need to deal with the contradictions of being epistemologically led by the powerful and the wealthy but identified, felt and needed most acutely by the subaltern. It would need to be 
very broadly legitimate, representing the 'expansion of international society' that Bull and Watson (1984) once foresaw. Liberal peacebuilding and neoliberal statebuilding, along with the liberal international community were staging points along this path in the twentieth century. A new stage would require a form of global social democracy, with a set of centralized institutions to agree on core issues and standards, but which must be representative of a decentralized framework of fluid, local politics, and mobile forms of political agency across scales and networks. This represents a next stage for the international system and peace architecture. This stage would represent an architecture of great complexity, however, which itself carries significant costs and risks.

There is a need for a centralized capacity to address human needs and rights across the globe through systems of intervention and redistribution in a commonly agreed framework of institutions, and a decentralized and contextualized framework in which existing and new human needs and rights can be negotiated and transmitted upwards. The new, more poly-centric, post-colonial world of 'emerging powers' must be recognized, probably mainly 'from below' in bottom-up and ethnographic terms. In addition, emancipatory claims for decentralized multi-verticality connected to existing multilateral systems, for mobility across scales, and more localized horizontal forms of governance (as opposed to the top-down approach of the liberal peace architecture) would also be necessary. Hints of much of this can be seen already in the existing international architecture. UNCTAD, for example, is concerned with fair distribution of resources and the control of private capital, a right to well-being and social justice ((Bull and Watson, 1984: 235), as reiterated in the Bamako Appeal of 2006, which sought to overcome north-south divides and replace what it saw as the northern militarized and neoliberal consensus with a more sensitive form of democracy and solidarity (ibid, 243). Again, this pushes against territorial sovereignty, expands liberal institutional thought and law upon contact with other post-colonial, post capitalist, post-Euro-centric and post-anthropocentric positionalities across the planet. It requires a balance of centralized and decentralized power and critical agency across networks that promote a peace connected to global justice.

Progress, power and intervention, and autonomy, are thus balanced in an actively contested rights system, spanning the local to global scales, driven by subaltern claims for more rights. So far however, only powerful states and occasionally alliances of states have been able to carry the day in responding to violence 
and promoting reform, which has been limited to their own norms, preferences, and interests, embedded in static architectures. Peace is thus contaminated by their preferences. Existing social and transnational frameworks for the negotiation of peace and order have limited agency when confronting large-scale problems, but they suggest for the future where peace is connected to conceptions of global justice, mobility across scales and networks, and much broader rights claims as key features (Weiss, 2009: 264). Drawing on critical theory as gathered together by Habermas, progressive forms of reason, law, and democracy, together provide the basis for dialogic methods through which conflict can be settled, and new and more emancipatory, ethical political orders might be achieved (Habermas, 1990). Such processes depend on complex networks, agency and mobility, in a post-colonial and multi-scalar, networked and mobile world of acute inequality and constantly emerging new layers of injustice: the only universal is the mediation of difference with the goal of a peace settlement, or a peace praxis connected to global justice in order to achieve long term sustainability. It means, as Stanley has observed in his assessment of UN attempts to build peace in Guatemala, both reforming power-structures and building new national institutions that contribute to domestic and international peace architectures, as well as working through existing local institutions which carry legitimacy authority and know-how in situ (Stanley, 2013: 8). Expanding rights in a post-liberal peace architecture require existing institutional layers of the peace architecture to be maintained, their contradictions ironed out, and also that new ones emerge to engage with new forms of conflict.

The difficulties with the relationship between the state, international actors, and global justice are well illustrated by the G77. It appeared to be a space for a progressive debate about north-south redistribution, about justice questions in the international system, and what might be done about it. It is also an avowed supporter of anti-imperialism, socialism and the sovereign state, spanning the New International Economic Order of the 1970s to the New World Order for Living Well of 2014. Its recent doctrine adds public services to the list of human rights and seeks a role for the state over the corporation. It calls for decolonization not from imperial powers but from capitalism with a view to broad forms of sustainability. It wants to see a broadening of the UN and the abolition of the Security Council (G77, 2014). Yet, it also reiterates the sanctity of state sovereignty, as the best way of supporting human rights and development, to assuage 
political interests. The history of the last 60 years has thrown significant doubt on this assumption and illustrated the difficulties in transcending sovereignty even where peace is the goal.

The western-created and backed order appears to be caught between more progressive demands that push beyond the dimensions of statehood and liberal internationalism, to which it is reluctant to concede, and autocratic or oligarchic tendencies of centralized state power or the networked fluidity of capital, towards which it is veering perceptibly. The UN, EU, and other western backed structures of global governance and their key state supports are at best now seeking to stabilize the current order, with all of its imperfections. This trend runs against the convergence of inter-disciplinary knowledge this article has attempted to synthesize about peace. Conservative and liberal thought appear to agree on security for the existing statessystem, and expanding capital over expanding rights and global justice for the moment, though this is being challenged by the Sustainable Development Goals as well as the "Sustaining Peace" agenda, which at least offers discursive prospects progress (UN, 2015, 2016, 2018).

Despite the tension between expanding rights and sovereignty over the scope of rights and intervention, actors involved in peacebuilding and statebuilding have responded by building an international peace architecture, which is heavily networked and multi-scalar though unfinished. In parallel, they have also protected the old liberal peace model and its static, territorialised model of citizenship, rights, and institutions. They are also dabbling with more complex understandings of world politics in a 'digital' era. It is widely accepted that social and economic rights have diminished in the post-Cold War, even though many of the political struggle claims of the world's conflict-affected citizens revolve around them, as for example since the 1970s in Timor Leste, hence the revived G77 interest in a new statement about progressive politics. ${ }^{4}$ There is little appetite for discussion of social justice even amongst the international community, however. It is generally seen by policy elites in the international civil service as being an issue that is too complex and too long term for the current system of international relations, organizations, and states to respond to. Thus, the international peace architecture has focused on building a discursive consensus

\footnotetext{
${ }^{4}$ Confidential Sources, Personal Interviews. UN Department of Peacekeeping Operations, New York, 31
} March 2014. 
between those making local claims for expanded rights and the authors of international doctrines for peacebuilding such as the Sustaining Peace agenda, expressed in ever more technocratic ways. This dual strategy is an attempt to avoid becoming moribund because of a loss of legitimacy (as occurred with the League of Nations in the 1930s). Perhaps a further response will be to engage increasingly with 'digital' and potentially automated strategies for peace, as a defense against ethical limitations, and in order to respond to subaltern claims for global justice. Conversely, states and bureaucracy-led or interest-led donors might easily return to sovereignty as a legalistic or bureaucratic form of self-limited conflict management, which reduces the ethical and emancipatory claims on global actors for expanded rights.

Tactically it has become clear across conflict-affected states that subaltern claims and civil society actors see human rights as a worthwhile basis for peace formation aimed at redesigning a more peaceful and just state and society, ultimately requiring a global framework if global justice is to be achieved. On the other hand, and in the recent context of many conflict affected states such as Cambodia (with the growth of Hun Sen's power), Cyprus (after the rejection of the referendum of the UN's “Annan Plan” in 2004), Northern Ireland (in particular with the role of the UK's Conservative leadership over its exit from the EU since 2016), or Colombia (with the reversion to nationalist politics in after the election in 2018), nationalist elites may reject a tendency towards expanded rights even if a peace process' survival depends upon it. Expanded versions of rights may threaten long-standing power structures, because they challenge the very structures that hegemonic power depends upon (for example, territorial sovereignty, social hierarchy, the control of capital or institutions). Ultimately, this is a structural contradiction upon which the momentum for expanded rights in response to subaltern claims might founder without a broader recognition of global justice as the raison d'etre of the international peace architecture.

\section{Conclusion}

The association of peace with human rights has had significant consequences for the evolution of the international system, the agency of subaltern actors, and the nature of intervention. Much of the debate about human rights and its relation to peace and order has focused on the realization of rights, especially when taken away (Taylor in DeGooyer, 2018: 106). The dynamic expansion of rights over time and from the 
subaltern perspective, according to their own agency in part, is less frequently dwelt upon. Human rights offer a tactical way forward for those interested in conflict resolution in light of the 'local turn' (Mac Ginty \& Richmond, 2013: 763-783), but should not be taken as a static framework for peacemaking within the relatively constrained liberal international architecture. An unintended consequence of human rights, which though ethically sophisticated has given rise to structural weaknesses in the international peace architecture, is that unless conceptions of rights are continually expanded as power structures are uncovered and challenged, as during the various recent "local", "micro", and "practice" sophistications in IR, philosophical and material matters of distributive and historical justice remain. Political legitimacy and authority are constrained in this case meaning that peace cannot be sustainable or is dependent upon broad and externalized interventionary practices.

From this perspective, 'norms cascades' do not merely refer to the transfer of rights-based discourses and policies from the global north to conflict-affected and developmental states elsewhere (Finnemore and Sikkink, 1998: 887-917), but rather to the continual expansion of normative claims against predatory power. Much of this would be in the reverse direction to the envisioned cascade of norms from Western state donors and institutions, and instead run bottom up from conflict-affected subaltern actors, across networks and scales to donors, international institutions, and INGOs. The normative changes that the international order has undergone since 1945 have led to expanded rights agendas and partly transcended territorial sovereignty (through the examples of the UN's multilateral system and the EU's integration model) already. Extended further, this logic suggests the emergence of a more mobile, networked, scalar, "anthropocenic" system requiring structural and well as political sustainability for peace and justice to be achieved. Within this framework new perspectives on the range of rights are provided by subaltern voices engaging with rights in the context of new technologies and concerns about sustainability. Consequently, new frameworks of intervention, governance, resilience, and agency, are also emerging (Chandler, 2018:159: Moyn, 2018: 11; Sassen, 2006: 291; Jessop, 2016: 225; DeGooyer, 2018, :4; Bell, \& Pospisil, 2017: 576-593; Lederach, 1995). This in hinted at in the recent development of debates about peace spanning negative, positive, hybrid and everyday versions illustrate the pressure on rights to expand following the logic of a 'right to have rights', rather than resting upon basic versions. The latter undermine their own legitimacy. 
Even within material, geopolitical, and geo-economic limits, as well as within the confines of political will, the direction of international policy indicate there is more potential that the states-system can acknowledge. The tendency of actors in the international system to resist subaltern pressure for more rights and the way in which it requires international actors to think beyond realist or liberal, constructivist and critical versions of international relations has brought the international peacebuilding architecture to the brink of a legitimacy crisis. ${ }^{5}$ It has also highlighted new potential as a result of such unintended consequences.

Thus, bringing human rights into the international peace architecture has led to a range of debates about the dynamics of resistance to oppressive state power, war-lordism, institutionalized injustice, and global or regional hegemony. The idea that only basic human rights can be defended on universal grounds via territorial sovereignty and liberal international institutions has long been contested in communitarian and post-colonial frameworks and increasingly evidence confirms that human rights are predisposed towards expansion far beyond those systems. Thus, interventionary practices have also expanded, captured by the constrained development of $\mathrm{R} 2 \mathrm{P}$ doctrine, creating a contradiction with universalism and practices of intervention. Responses are necessary for state and international level systems of governance to maintain their legitimate authority amongst grassroots, civil, and transnational, and international actors, as well as amongst many (but not all) international leaders. Preventing the loss of hard won rights and avoiding a reversion to imperial-subject status (Taylor, in Stephanie DeGooyer, 2018: 116) requires the expansion across normative and territorial boundaries of complex and sophisticated rights. This explains the critical pressure that has led, for example, security to be thought of as human security, and how frameworks of meaning and structure such as interests, norms, or the state itself are much more closely defined by their subjects' perspectives and agency. Networks, relationality, and mobility, connecting the subaltern to a complex fluid and multi-scalar system of actors, formal and informal, local, state and international, represent a new terrain of legitimate authority, which now needs to be considered in the attempt to connect peace, rights, and thus global justice. Social and economic systems can only be evaluated and reformed from the most exposed and precarious, subaltern, position in any polity from local global. Elites and power holders must find ways of mediating the claims from such peace formation signals if they are to maintain legitimate

\footnotetext{
${ }^{5}$ Confidential Source, Personal Interview, UNDPKO, New York, $7^{\text {th }}$ December 2017.
} 
authority (Richmond 2016). Any new peace settlement or form of peacebuilding would be aimed at providing a complex assemblage, mobile and networked solution to the widely varied structural, normative, temporal, political, social, economic, and geographic conflicts that travel with globalization. Injustices across these terrains required networked and hybrid peace settlements across a global terrain of difference.

In the past, debates around such matters have aimed towards uncovering the idealist conditions of a world state or a world confederation (Wendt, 2003: 491-542) in order to lock in progressive international reforms, but subaltern claims which lead to global justice under mobile, networked, scalar and hybrid conditions for peace point to the need to think about emancipatory forms of global governance. How such claims might be amplified and locked into a reformed peace architecture is a question that now faces us. The 'stable' grounds of the current states-system and international architecture have become inadequate, though international citizenship, a global commons, and 'community of the governed' has become clear (Goulder, 2015: Foucault, 1984).

Peace may instead be understood by the way in which its subjects create processes of positionality arbitrage through everyday mobility, ever-denser global networks, and multi-verticality, perhaps bridging the ethical and practical gaps within the state and institutional nodes of the twentieth century's peace architecture. New 'peace agreements', institutions, and settlements will probably need to be mediated between the claims of mobile, transversal, and transnational social movements and networks across scales and those elements of historical power remaining at the social, state, and international levels through multivertical modes of engagement. Such dynamics are calling into being new understandings of the breadth of peace across time, space, identity, rights, and resources, and relatedly of the rethinking of 'government' across a networked and scalar mobile world, where widely available information is politics rather than power, in potentially the most deeply cooperative international system that has ever existed. The qualities of mobility, hybridity, and global justice across networks of relationality in time and space, being cognizant of environmental limits, are becoming the dominant motifs of new and more social forms of peace thinking. 


\section{Bibliography}

Alther G (2006). “Colombian Peace Communities: The Role of NGOs in Supporting Resistance to Violence and Oppression.” Development in Practice, vol. 16, no. 3/4, pp. 278-291

Anievas A, N. Manchanda, and R. Shilliam, eds., (2015) Race and Racism in International Relations:

Confronting the Global Colour Line (New York: Routledge).

Arendt, H (1951) The Origins of Totalitarianism, New York, Harcourt Brace, 1951

Bailliet CM \& KM Larsen (2015), “Introduction”, Promoting Peace Through International Law, OUP.

Bellamy, Alex J. (2015). "The Responsibility to Protect Turns Ten". Ethics \& International Affairs. 29 (02): $161-185$.

Bell, C \& Pospisil, J. (2017) "Navigating Inclusion in Transitions from Conflict: The Formalised Political Un settlement”. Journal of International Development, Vol.29, pp.576-593

Boege,V, Ann Brown, Kevin Clements et al. (2008). "States Emerging from Hybrid Political OrdersPacific Experiences”.Brisbane: Australian Centre for Peace and Conflict Studies, Occasional Paper No. 11. Bull H and Adam Watson, eds., (1984) The Expansion of International Society (Oxford: Oxford University Press.

Cahill- Ripley A and Diane Hendrick (2018), "Economic, Social, and Cultural Rights and Sustaining Peace" Geneva: Friedrich Ebert Stiftung.

Carr, E. H. Carr (1939), Twenty Years Crisis (London: Macmillan).

Chandler, D. (2010), International Statebuilding: The Rise of Post-Liberal Governance, London: Routledge. Chandler, D (2018) Ontopolitics in the Anthropocene, London: Routledge

Confidential Source (2017), Personal Interview, UNDPKO, New York, $7^{\text {th }}$ December.

Confidential Sources (2014) Personal Interviews. UN Department of Peacekeeping Operations, New York, 31 March.

De Tocqueville, A (2000) Democracy in America (Chicago: The University of Chicago Press, [1835/40]

DeGooyer S (et al) eds., (2018) The Right to Have Rights, London: Verso, 2018.

Di Palma, G (2103) The Modern State Subverted (Colchester, UK: ECPR). 
Dürbeck D, C. Schaumann and H. Sullivan (2016), "Human and Non-human Agencies in the

Anthropocene," Ecozon 6, no. 1: 122, 118-136.

Elden, E (2013) The Birth of Territory (Chicago: The University of Chicago Press).

Finnemore, M and Kathryn Sikkink (1998), International Norm Dynamics and Political Change, International Organization, Volume 52, Issue 4, pp. 887-917.

Foucault, M (1984) “Face aux gouvernements, les droits de l'homme,” Liberation, 30 June.

G77 (2014), New World Order for Living Well.

Goulder, B (2015) Foucault and the Politics of Rights (Stanford: Stanford University Press)

Habermas, J (1990) Moral Consciousness and Communicative Action (Translated by Christian Lenhardt and

Shierry Weber Nicholsen. Introduction by Thomas A. McCarthy) (Cambridge, MA: The MIT Press.

Hathaway OA \& Scott Shapiro, (2017) The Internationalists and their Plan to Outlaw War, London: Allen Lane.

Hinnesbush R (2015), “Globalisation, democratization, and the Arab Uprising,” Democratization 22, no. 2: $335-357$.

Hudson, M (2003) Global Fracture (Ann Arbor, MI: University of Michigan)

Hurrell, A (2007) On Global Order: Power, Values, and the Constitution of International Society (Oxford:

Oxford University Press)

Ikenberry, JG (2011) Liberal Leviathan (Princeton: Princeton University Press).

Jessop, B (2016) The State, Past Present and Future, Cambridge: Polity

Keck ME and K. Sikkink (1998), Activists without Borders (New York: Cornell University Press).

Lederach, JP (1995) Preparing for Peace: Conflict Transformation Across Cultures, Syracuse University Press.

Mac Ginty R \& Oliver P Richmond, (2013) “The Local Turn in Peace Building: a critical agenda for peace”, Third World Quarterly, Vol. 34, No.5, pp.763-783

Marchettia, Raffaele and Nathalie Tocci (2009), "Conflict society: understanding the role of civil society in conflict”, Global Change, Peace \& Security, Vol. 21, No. 2, pp.201-217. 
Marshall TH (2009), “Citizenship and Social Class,” in Inequality and Society, eds. J. Manza and M. Sander (New York: W. W. Norton and Co).

Millar, G. (2018). 'Engaging Ethnographic Peace Research: Exploring an Approach'. International Peacekeeping, vol. 25, no. 5, pp. 597-609.

Morton, S (2007) "The Subaltern: Genealogy of a Concept", in Gayatri Spivak, Ethics, Subalternity and the Critique of Postcolonial Reason, Oxford: Polity, pp. 96-97.

Moyn, S (2018) Not Enough: Human Rights in and Unequal World, Belnapp Harvard University Press.

Owen, Taylor (2015) Disruptive Power: The Crisis of the State in the Digital Age, OUP.Hovey, Rebecca (2004). “Critical Pedagogy and International Studies: Reconstructing Knowledge Through Dialogue with the Subaltern”. International Relations Vol 18 issue: 2: 241-254.

Pattberg P and O. Widerberg (2015), “Theorising Global Environmental Governance,” Millennium 43, no. 2 : 684-705.

Piketty, $\mathrm{t}$ (2014) Capital in the 21 st century (Boston, MA: Belknap Press).

Plato, Republic, Book VIII (New Haven, CT: Yale University Press, 2006 [380 BC])

Michael Pugh (2006) "Post-war economies and the New York dissensus", Conflict, Security \& Development, 6:3, 269-289.

Qin, Yaqing (2018) A Relational Theory of World Politics, Cambridge University Press.

Richmond, Oliver P \& Franks, J (2009), Liberal Peace Transitions, Edinburgh University Press.

Richmond, Oliver P. (2005) The Transformation of Peace, London: Palgrave

Richmond OP (2014), Failed Statebuilding, Yale University Press, 2014.

Richmond, OP (2015)“Dilemmas of a Hybrid Peace: Negative or positive?," Cooperation and Conflict 50, no. 1.

Richmond, OP (2016) Peace Formation and Political Order (Oxford: Oxford University Press). Rist G (1996), The History of Development (London: Zed Books)

Rostow, W (1960) The Stages of Economic Growth: A Non-Communist Manifesto (Cambridge: Cambridge University Press). 
Sassen, S 2006) Territory, Authority, Rights, Princeton University Press

Slaughter, AM (2004) A New World Order (Princeton: Princeton University Press)

Slaughter, Anne Marie (2004) "Sovereignty and power in a networked world order", Stanford journal of international law 40(2), pp.283-327.

Stanley, W (2013) Enabling Peace in Guatemala, Lynne Rienner.

UN (2015). "Transforming our world: the 2030 Agenda for Sustainable Development", UN General Assembly A/RES/70/1, 25th September

UN Department of Peacekeeping Operations (2008), Capstone Doctrine: Peacekeeping Operations:

Principles and Guidelines (New York: DPKO).

UN General Assembly and Security Council (2018), "Peacebuilding and Sustaining Peace", Report of the UN Secretary General, A/72/707-S/2018/43, $18^{\text {th }}$ January.

UN General Assembly, (1984). Right of peoples to peace”, UN General Assembly Resolution 39/11

UN General Assemby (1966) International Covenant on Economic, Social and Cultural Rights (ECOSOC), United Nations General Assembly Resolution 2200A (XXI), $16^{\text {th }}$ December

UN Security Council Resolution (2016) S/RES/2282.

UN, (2018) "High-level Meeting on efforts undertaken and opportunities to strengthen the United Nations' work on peacebuilding and sustaining peace”, 24 25 April

United Nations (2015), "The Challenge of Sustaining Peace: Report of the Advisory Group of Experts on the Review of the Peacebuilding Architecture", UN Doc. A/69/968-S/2015/490, June 30.

Visoka, Gezim (2017) Shaping Peace in Kosovo, Palgrave Macmillan.

Vucetic, S (2011). The Anglosphere: A Genealogy of a Racialized Identity in International Relations (Stanford: Stanford University Press).

Weiss TG and A. E. Abdenur (2014), "Introduction: Emerging powers and the US - what kind of development partnership?," Third World Quarterly 35, no. 10: 1749-1758

Weiss TG, T. Carayannis and R. Jolly (2009), “The 'Third' United Nations,” Global Governance 15, no. 1: 123-142. 
Weiss, TG (2009) “What Happened to the Idea of World Government," International Studies Quarterly 53, no. 2

Wendt, A (2003) "Why a World State is Inevitable," European Journal of International Relations 9, no. 4:

Zink, A (2008) "Northern Ireland and Cyprus: Towards a Typology of Intercommunal Conflict in the European Periphery", Nationalism and Ethnic Politics, 14:4, pp.579-612. 